mentation, which is developing a world inventory of scientific abstracting services, and establishing an international clearing house for information on abstracting services and techniques. The Federation has also recommended the formation of a Group on Mechanical Storage and Retrieval; the Ford Foundation has announced a grant of 8 million dollars to the Council on Library Resources, Ine., for continued research to improve library methods, with emphasis on ways of storing and finding information in the library of the future.

\section{Peasant Agriculture in the Tropics}

A VALUABLE review of different systems of peasant agriculture in various parts of the tropics is made by E. W. Momber, School of Agriculture, University of Cambridge, in a recent issue of Rural Life (6, No. 1; 1961). Momber analyses existing practices in Northern Rhodesia, Tanganyika and Nigeria and shows that nearly all peasant systems were evolved to carry a subsistence economy where there was plenty of land and few people, and that the traditional systems of peasant agriculture are not basically unsound for the purpose for which they were designed. To-day they are being asked to perform tasks which they were not designed to carry out.

\section{Sheep Husbandry in Northern Ireland}

A FEATURE of farming in Northern Ireland during recent years has been, says the Ministry of Agriculture of Northern Ireland (Government of Northern Ireland: Ministry of Agriculture. Leaflet No. 47: Sheep Husbandry. Pp. 26. Belfast: Ministry of Agriculture, 1961), an increase of the number of sheep reared from 654,000 in 1945 to $1,097,000$ in 1960 . Important factors in this development have been the improvement in pasture manuring and management and the relatively high cost of store cattle. The leaflet discusses breeds of sheep, the types and sizes of sheep flocks, the mating, management and diseases of sheep and the handling and care of wool. It is written in clear, non-technical language and is certainly a very good exchange for a postcard sent to Belfast.

\section{Damage to Maize in Nigeria}

Examinatron of samples of maize obtained from market traders at Ibadan, Nigeria, over a period of fourteen months by G. H. Caswell of the Department of Agriculture, University College, Ibadan, Nigeria, showed that damage to maize by Calandra oryzae, L., the only important pest of stored maize in this region, is slight compared with damage by the same insect in other countries (J. West Africa Sci. Assoc., 6, No. 1, February 1961). This is probably due to the fact that farmers use a system of shifting agriculture, and store maize on their farms where Calandra is not endemic. Should the practice of central storage become more common, damage is likely to increase.

\section{The Institution of Metallurgists}

AT the seventeenth annual general meeting of the Institution, held in London on May 17, Dr. N. P. Allen, superintendent of the Metallurgy Division, National Physical Laboratory, was elected president for the year 1961-62, in succession to Mr. W. E. Bardgett. The following elections were also made: Senior Vice-President, Dr. E. G. West, technical director, Aluminium Development Association; VicePresidents, F. Dickinson, director and general manager of the Development and Research Department, International Nickel Co. (Mond), Ltd., and Dr. L.
Northcott, principal superintendent, Materials Division, Armament Research and Development Establishment, Fort Halstead (War Office); Honorary Treasurer, L. W. Derry, head of the Metallurgy Department, Battersea College of Technology; Members of Council, H. Morrogh, director, British Cast Iron Research Association, Alvechurch, Birmingham, S. S. Smith, research manager, Imperial Chemical Industries, Ltd., Metals Division, Kynoch Works, Witton, Birmingham, and Dr. J. C. Wright, reader in Industrial Metallurgy, Birmingham College of Advanced Technology.

\section{The Linnean Society of London}

Ax the anniversary meeting of the Linnean Society of London, held on May 24, the following were elected officers for the session 1961-62: President, Prof. Thomas Maxwell Harris; Treasurer, the Earl of Cranbrook; Secretaries, Dr. C. R. Metcalfe (Botany), Dr. H. G. Vevers (Zoology), Dr. John Smart (Editorial); Vice-Presidents appointed were: Prof. A. R. Clapham, Prof. C. F. A. Pantin, the Earl of Cranbrook and Dr. W. T. Stearn. New Members of Council elected : Mr. P. R. Bell, Mr. J. B. Gillett, Prof. Tom Harris, Dr. D. M. Kermack and Dr. Sydney Smith. Linnean Gold Medals were presented to Mr. Edmund William Mason and Dr. Frederick Stratten Russell. Dr. Mary Agnes Chase, of the United States, and Dr. Franz Petrak, of Austria, were elected foreign members.

\section{The H. G. Wells Society}

The H. G. Wells Society has recently been founded to promote and encourage an active interest in, and an appreciation of, the life and work of one who made such great contributions in many directions during the first half of this century. Educated as a scientist, he inspired persons of all persuasions to take nothing for granted and to examine fundamental principles in all activities, particularly Government, history, planning, possibilities of science and its potential assistance to mankind. The new Society is non-political and non-sectarian, and seeks only to find that which is good in the thought, word and deed of a great man and which can be used as a memorial to one who filled a great gap in human thought. Further information can be obtained from the hon. secretary, Mr. J. R. Hammond, 39 Rugby Road, West Bridgford, Nottingham.

\section{The Royal College of Surgeons of England}

A GRANT of $£ 250,000$ has been made to the Royal College of Surgeons of England by the Wolfson Foundation. The gift will be applied primarily to the provision, furnishing and equipment of the Hunterian Museum. The Museum-now being rebuilt following its destruction by bombing - is expected to be finished by the spring of 1962 , and is to house the collection of anatomical and pathological specimens collected by John Hunter and purchased by the Government of the day, after his death in 1793 .

\section{College of Advanced Technology, Birmingham}

IN support of the College policy to promote and develop research activities, Messrs. Joseph Lucas, Ltd., Birmingham, have established a fellowship, to be known as the Joseph Lucas research fellowship, in production engineering which will be tenable normally for a period of two years with provision for extension to three years, and valued at $£ 1,300-£ 1,500$ per annum. 